\title{
22. STRATIGRAPHY AND TECTONIC INTERPRETATIONS OF MULTICHANNEL SEISMIC REFLECTION RECORDS ACROSS THE JAPAN TRENCH OFF SANRIKU, NORTHEASTERN JAPAN 1
}

\author{
Seiji Tsuboi, Department of Geophysics, Faculty of Science, University of Tokyo \\ and \\ Hideo Kagami and Hidekazu Tokuyama, Ocean Research Institute, University of Tokyo ${ }^{2}$
}

\begin{abstract}
New F-K migrated multichannel reflection profiles establish the seismic stratigraphy between Sites $438 / 439$ on the deep-sea terrace and Site 584 on the midslope terrace of the continental slope off Sanriku, northeastern Japan. Prominent downlappings of the basal strata are observed at places where the Cretaceous basement has been uplifted, and surface reflectors terminate or toplap at the same place. Uplift of the basement causes tensional stress and arching in the overlying Neogene strata along the outer margins of the midslope terrace and deep-sea terrace, forming both downlapping and toplapping. Graben within the subducted lithosphere may influence tectonic erosion along the base of the overlying prism.
\end{abstract}

\section{INTRODUCTION}

The two main objectives of this report are (1) to establish a new seismic stratigraphy that clarifies the subsidence and uplift history of the continental margin off northern Honshu; and (2) to interpret tectonic mechanisms associated with subduction in the toe area of the accretionary wedge.

It was surprising to find that the steep dips of bedding were developed throughout almost the entire section of Site 584 at the midslope terrace. Contrary to the seismic section across the deep-sea terrace, where landward-dipping normal faults were observed near Site $438 / 439$, no visible faults were identified on the seismic sections near Site 584 . The shipboard party believed, however, that small landward-dipping faults must have developed to compensate for steep bedding dips co-occurring with the nearly horizontal seismic and paleontologic correlation among the three holes drilled at Site 584 (Karig et al., 1983).

Three seismic sections from Japan National Oil Corporation (JNOC) and two from the Ocean Research Institute (ORI) (ORI 78-3, ORI 78-4) cross the northern part of the Japan Trench (Fig. 1 and Nasu et al., 1980; Nasu et al., 1979). During the presite survey for Leg 87, additional multichannel seismic sections (ORI 80-2 and ORI 81-9) were obtained (Kagami, Tokuyama, et al., 1980; Kagami et al., 1981; Tokuyama et al., 1982). Line ORI 80-2 crosses JNOC A and extends to ORI 78-3, on which Site 584 is situated, affording the opportunity to correlate drilling results and seismic reflectors between Sites $438 / 439$ and 584. Interpretation of the seismic section corresponds in general to the drilling results of Leg 87 .

\footnotetext{
${ }^{1}$ Kagami, H., Karig, D. E., Coulbourn, W. T., et al., Init. Repts. DSDP, 87: Washington (U.S. Govt. Printing Office).

2 Addresses: (Tsuboi) Department of Geophysics, Faculty of Science, University of Tokyo, Bunkyo, Tokyo 113, Japan; (Kagami and Tokuyama) Ocean Research Institute, University of Tokyo. 1-15-1 Minamidai, Nakano, Tokyo 164, Japan.
}

Also, the results allow us to discuss the origin of the downlap of the Miocene horizons.

\section{METHODS}

\section{Seismic Reflection Methods}

A multichannel seismic reflection survey was carried out across the Japan Trench off the Sanriku district of northeastern Japan during the KH80-1 and KH81-3 cruises. A 12-channel seismic system composed of sound source, hydrostreamer, amplifier, and recording blocks was used in these cruises (Kagami, Takahashi, et al., 1980).

The sound source was a 300 -cubic-inch air gun operated at a pressure of approximately $80 \mathrm{~kg} / \mathrm{cm}^{2}$ and fired at a time interval equivalent to approximately $50 \mathrm{~m}$. The hydrostreamer block consists of 12 active sections, 3 stretch sections, 3 depth/distance sections, and a tail section. The length of each active section is $50 \mathrm{~m}$. The amplifier block amplifies, filters, multiplexes, and converts (analog to digital-A/D) the 12-channel input signals. Signals from the 12 active sections are fed into 12-channel preamplifiers with preset gains and band-pass filters. The observed signals are then filtered through a band-pass of 0 $128 \mathrm{~Hz}$. After multiplexing is complete, serial signals are amplified in 12 -dB steps up to $84 \mathrm{~dB}$, depending on each input level, and then digitized by a 15-bit A/D converter. Record length and sampling interval are $4000 \mathrm{~ms}$ and $4 \mathrm{~ms}$, respectively.

\section{Data Processing}

Almost all of the computer programs used for signal processing applied in this study were originally written by Takeuchi and Saito (1982) and were executed at the Computer Centre of the University of Tokyo. The procedure of analysis is a standard one. First we transformed the data to SEG-X format, for handling with our program. Because there seems to be a low-frequency $(\sim 10 \mathrm{~Hz})$ noise in some of the original records, we performed band-pass filtering $(10-60 \mathrm{~Hz})$ before stacking. After we made common depth point (CDP) gathers, we applied normal move out (NMO) correction with velocity analysis. The result of the velocity analysis shows no significant difference with that of Kagami and others (1981). Next we applied a perstack deconvolution $(40 \mathrm{~ms})$; then we performed 6-fold stacking, 200-ms deconvolution, and $10-50-\mathrm{Hz}$ band-pass filtering. Finally, we displayed the seismic section.

To remove the diffraction wave from some parts of the section, we performed an F-K migration. By the use of an FFT (fast fourier transform), we can perform an F-K migration easily, but if the lateral velocity change is significant, we cannot apply it. In the case of these recorded sections, the lateral velocity gradient seems to be small and the result is satisfactory. 


\section{DESCRIPTION OF MAJOR REFLECTORS}

Several characteristic reflectors are identified in the continental slope off Sanriku, northeastern Japan. Some of the reflectors were successively traced from Sites 438/ 439 to 584 through seismic Lines JNOC 1, JNOC A, ORI 80-2, and ORI 78-3, (Fig. 1). These reflectors are recognized as follows, mainly based on drilling results.

Reflector $\mathbf{Y}$ is relatively continuous, and above this reflector onlapping structure occurs, e.g., at Shot Point (SP) 900 in Figure 2.

Reflector $\mathbf{X}$ has a limited continuity and large amplitude in the seismic section. Locally, it represents sediment fill of the forearc basin and is dated as Pleistocene at Site 438.

Reflector C is relatively continuous; locally it merges with a subsidiary reflector and forms a large-amplitude signal. Dated as the late Pliocene, it perhaps corresponds to the boundary between Lithologic Subunits $2 \mathrm{~A}$ and $2 B$ at Site 438, a change from clay and diatom ooze to claystone and diatomite (Kagami et al., 1981; von Huene et al., 1980). This boundary also corresponds to a velocity increase from 2.25 to $2.34 \mathrm{~km} / \mathrm{s}$ measured by sonobuoy (Murauchi and Ludwig, 1980). The numerous faults cutting through this reflector from the basement are thought to be normal faults (fig. 4 in Kagami et al., 1981).

Reflector E (late Miocene; 6-7 Ma) has limited continuity and large amplitude. At Site 438, this reflector corresponds to the boundary between Lithologic Subunits $2 \mathrm{~B}$ and $2 \mathrm{C}$ with increasing amounts of clay below the boundary, but it also corresponds to a hiatus at 6-7 Ma (Akiba, 1983). Above this reflector, onlapping structures mark Pliocene transgression over the continental slope area (SP 1120 in Fig. 2).

Reflector F (middle Miocene, 13-14 Ma) is less prominent than Reflector $\mathrm{E}$ in both continuity and amplitude. This reflector corresponds to the boundary between Lithologic Subunit 2C and Unit 3 at Site 438, a 13-14 Ma unconformity (Akiba, 1983). Under this reflector, ash content increases and reflectors show toplap or truncations (SP 700 in Fig. 3).

Reflector G (early Miocene) is relatively continuous and has a large amplitude. This reflector corresponds to the boundary between Lithologic Units 3 and 4 at Site 438 , a boundary which separates vitric diatom claystone above from clayey siltstone below.

Reflector $\mathbf{J}$ is relatively continuous and has a large amplitude. This reflector corresponds to the boundary between Lithologic Units 6 and 7 at Site 438, which marks a pronounced unconformity between the Cretaceous and Oligocene. This reflector also corresponds to a velocity change of 2.09 to $3.25 \mathrm{~km} / \mathrm{s}$ as measured by ocean-bottom-seismometer (OBS) observations (Nagumo et al., 1980 ) and to that of 2.34 to $2.80 \mathrm{~km} / \mathrm{s}$ as recorded by a sonobuoy survey (Murauchi and Ludwig, 1980).

Saki and others (1980) reported synthetic seismograms derived from the sonic and formation density logs at Sites 438 and 439. Reflections with prominent amplitude in the synthetic seismogram correlate well with those on the seismic record within a limit of half phase above
Reflector E and one phase below it. Reflectors X and C have a characteristic pattern in both sets of logs and are traced for long distances. Lithologic changes in the deeper section cause high-amplitude Reflectors E and F.

\section{TECTONIC INTERPRETATION OF THE SEISMIC SECTION}

The seismic section ORI 80-2 parallels a broad depression or valley on the continental slope and is oriented perpendicular to the trench (Fig. 1); therefore, the sedimentary section at ORI $80-2$ is thicker than at JNOC 1 , located along a broad culmination of the continental slope. At SP 1020, Profile ORI 80-2 crosses JNOC A (Fig. 2), along which most reflectors can be traced from Sites 438/439. From SP 960 landward on ORI 80-2, Reflector $\mathrm{G}$ is identified above Reflector J. For about 40 $\mathrm{km}$, from SP 100 to 900 (Figs. 2-4), Reflector G is missing in an area probably underlain by a ridge of Cretaceous basement uplifted during the Paleogene or early Miocene (Kagami et al., 1981). The ridge constitutes outer margin of the Sanriku deep-sea terrace (Nasu et al., 1980). Downlappings of the middle Miocene section occur at two places on the ridge; the first place is situated at SP 600-700, where strata lower than Reflector F downlap onto Reflector J (Fig. 3), and the second place is located at SP 100-300 (Fig. 4). The downlapping of strata was previously interpreted to result from onlap onto a regional high, indicating a marine transgression over an unconformity (Nasu et al., 1980). We propose, however, that the downlapping geometry was caused by the series of normal faults and clockwise rotation of beds, which are only observed at the basement uplift areas. Local uplifts have developed at the outer margin of the midslope terrace and deep-sea terrace since the middle Miocene. The surface reflectors toplap or truncate within (or slightly landward of) the area where the downlaps develop. Reflector Y truncates at about SP 750 (Fig. 2), and Reflector X at about SP 200 (Fig. 4). These facts indicate a strong relationship between downlapping of the basal reflectors and toplapping of the surface reflectors at the same place. Both phenomena were formed by uplifting of the basement at the margin of these terraces. From the age of the surface reflectors and from drilling results of Site 584 (site chapter, Site 584, this volume), the main phase of the local uplifting is estimated to have occurred since the late Pliocene. The reason for uplift could be an increase in the accumulation rate of diatomaceous sediments since the late Miocene in the northern Japan Trench area (site chapter, Site 584, this volume).

In another example of toplapping, Reflector $\mathrm{C}$ truncates at SP 180 on Line ORI 78-3 (Fig. 5). These sequential truncations of reflectors from Y (upper Pleistocene), $\mathrm{X}$ (lower upper Pleistocene), to C (upper Pliocene) toward the trench axis are once more encountered at SP 270, the location of DSDP Site 584 (Fig. 5). We recovered lower Pliocene strata at very shallow sub-bottom depths at Site 584 and steep dips of bedding which reached $70^{\circ}$ near the bottom of the hole (Karig et al., 1983). On seismic Profile ORI 78-3, the lower strata downlap between SP 0 and 300 (Fig. 5), perhaps representing mi- 


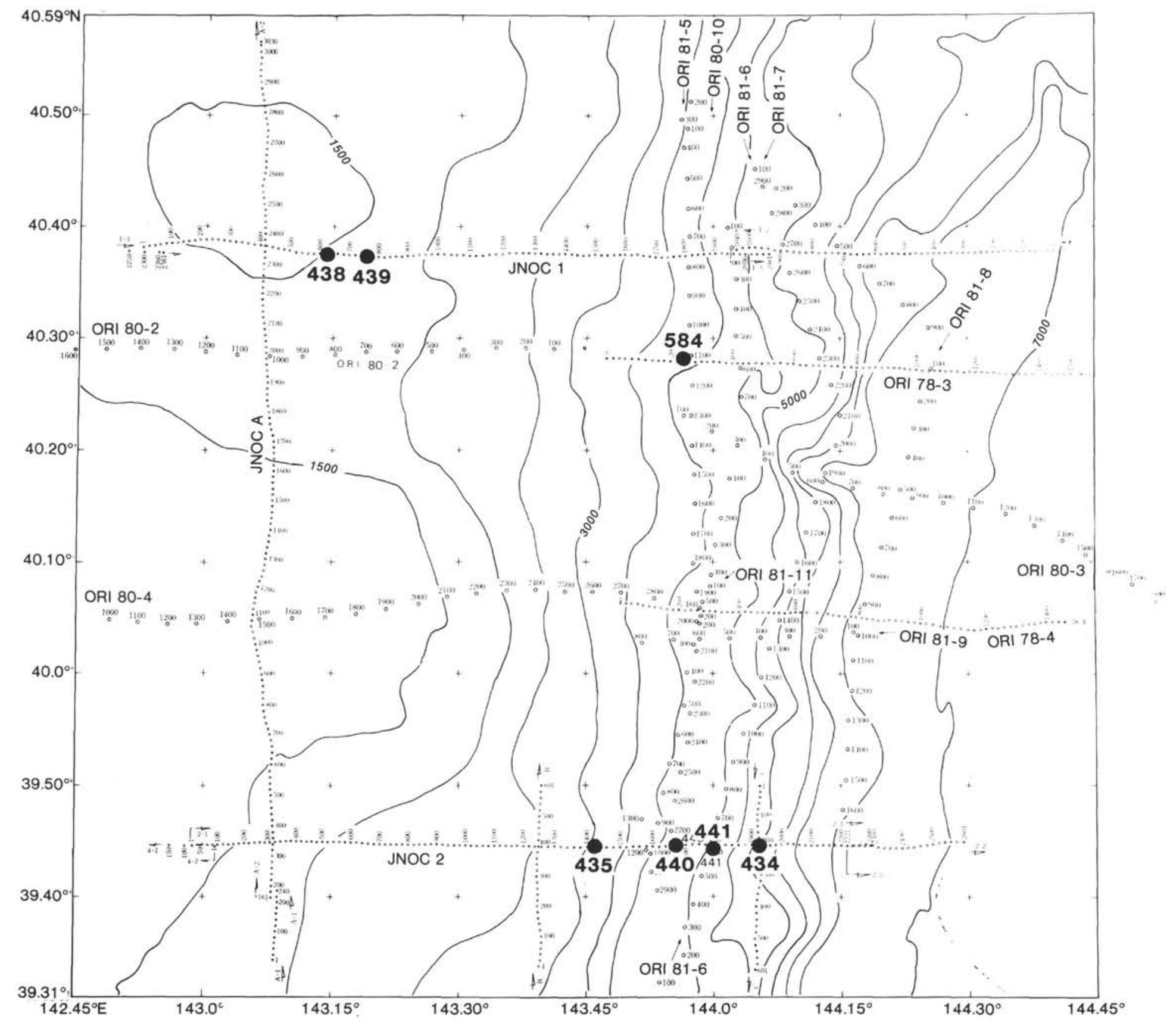




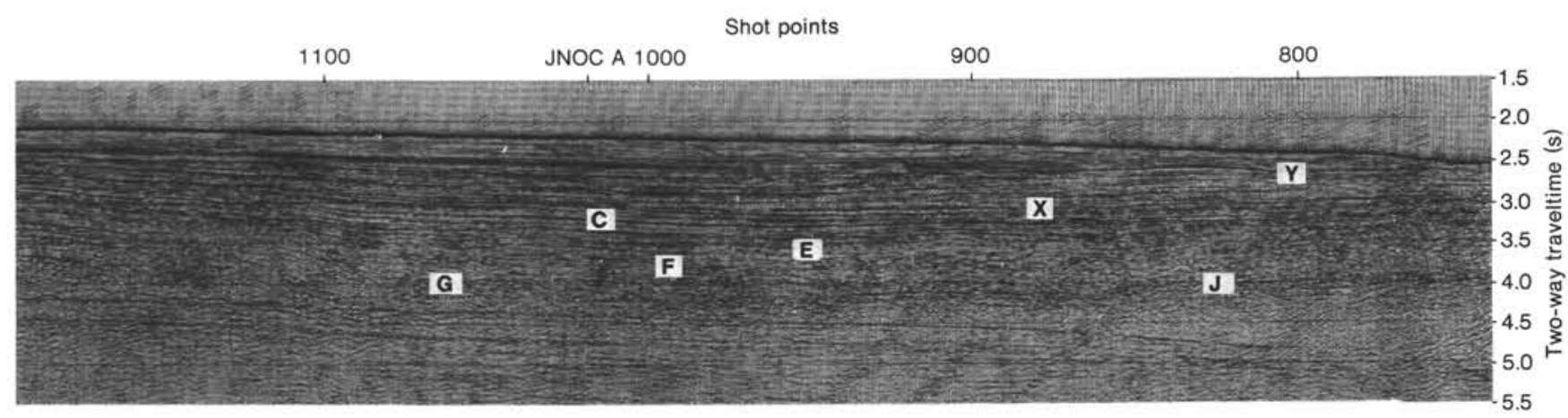

Figure 2. Common-depth-point stacked traces of ORI 80-2 (SP 740 to 1195). Capital letters inside profile indicate reflectors.

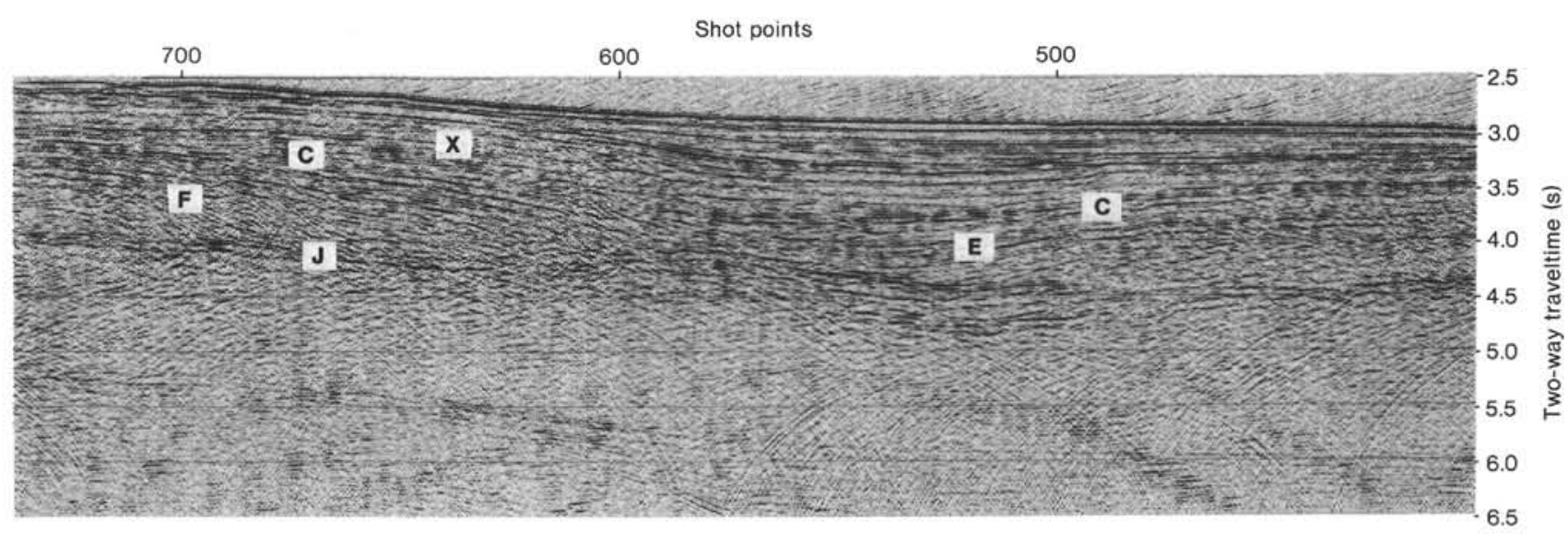

Figure 3. Migrated section of ORI 80-2 (SP 405 to 740). Velocity used to perform migration was $2000 \mathrm{~m} / \mathrm{s}$. Capital letters as in Figure 2.

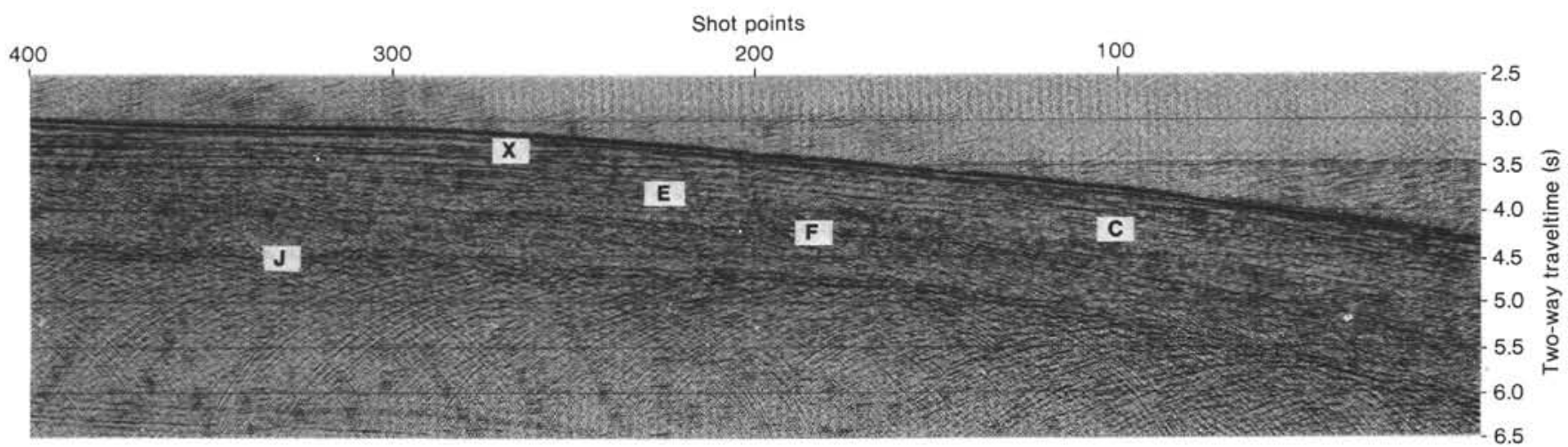

Figure 4. Migrated section of ORI 80-2 (SP 0 to 400). Velocity used to perform migration was $2000 \mathrm{~m} / \mathrm{s}$. Capital letters as in Figure 2.

crofracturing instead of large-scale faulting. Although this relationship differs little from the above-mentioned cases on the uplifted ridge at the outer margin of the deep-sea terrace, it suggests that this site is also situated on another active, uplifted ridge that forms a midslope terrace on the trench slope. The basement uplift at the outer margin of the deep-sea terraces and midslope terraces might be caused by seismotectonic deformation at the consuming plate boundary (Nagumo, 1970).

The seismic stratigraphy indicates that Reflector $\mathrm{F}$ can be traced over the entire continental slope except for a distance of $\sim 5 \mathrm{~km}$ on ORI 80-2 (near SP 550, Fig. 3).
This gap does not indicate emergence of the Oyashio landmass but is related to some local phenomenon. Because Reflector F is observed over almost the entire continental slope, we could safely say that the entire continental slope is under the depositional environment. Drilling results at Site 584 also indicated abyssal bottom conditions since the early middle Miocene (site chapter, Site 584 , this volume).

\section{TRENCH ACCRETIONARY WEDGE}

The Japan Trench and base of the landward slope are shown in Profile ORI 81-9 (Fig. 6), which is situated just 


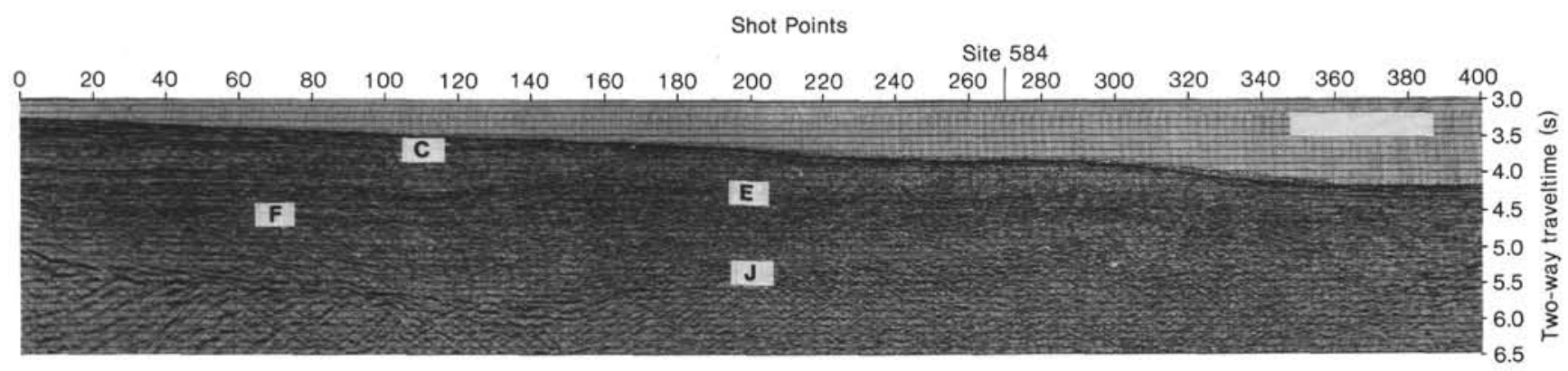

Figure 5. Migrated depth section of ORI 78-3 (SP 0 to 400). This section was prepared by JNOC through the courtesy of Dr. Yasufumi Ishiwada. Capital letters as in Figure 2.

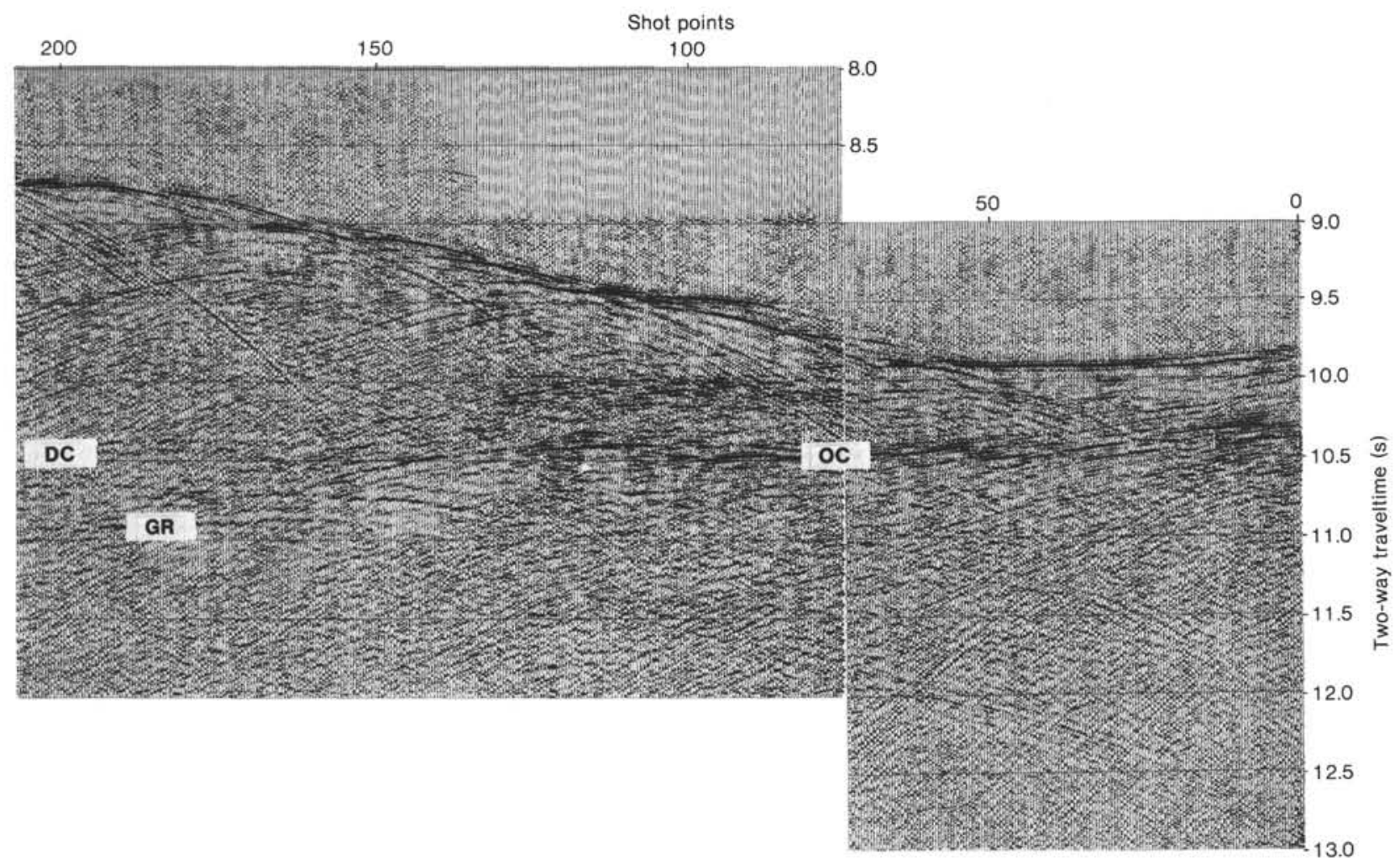

Figure 6. Common-depth-point stacked traces of ORI 81-9 (SP 0 to 210) showing the accretionary toe of the Japan Trench. OC: ocean crust, GR: graben, DC: décollement.

to the south of ORI 78-4. A well-developed graben can be seen at SP 150 landward of the trench axis (GR in Fig. 6). The surface of the subducted ocean crust drops to a depth of more than $1000 \mathrm{~m}$ sub-bottom, and the structure is quite similar to the graben shown on the outer trench slope (Hilde, 1983). An important feature displayed on our profile is a décollement near the top of the graben at about $10.5 \mathrm{~s}$ in two-way traveltime (DC in Fig. 6). The décollement is represented by a line from horst to horst and appears to be a straight-line extension of the top surface of oceanic Layer IIA (Tokuyama et al., 1982). Thrust faults prevailing in the toe of the accretionary wedge seem to verge with the décollement in the lower part of the sequence.

Hilde (1983) proposed a mechanism of subduction of trench-fill sediments within grabens developed on the out- er trench slope and named it the chain-saw mechanism. The normal fault system of the graben thus still appears to be active even after subduction beneath the inner slope. Tensional events have occurred in the upper portion of the subduction plate as far as $100 \mathrm{~km}$ landward from the trench axis (Yoshii, 1977). Activity on the normal faults increases the vertical offset between the floor of the graben and the décollement. The development of the décollement above the graben leads to the conclusions that accretionary sediments are perhaps scraped off, then once again incorporated to the ocean plate and subducted.

There is another hypothesis which explains subduction erosion. Kagami and others (in press) reported seismic thrust-faults developing in the accretionary wedge. They argued that whether these faults produce subduction or accretion depends on their location. When the 
thrusts develop or migrate into the accretionary wedge, that causes accretion; when they develop or retreat into the continental crust, that causes subduction. On the other hand, Moore and Biju-Duval (1984) pointed out that rapid accumulation of sediments in the trenches causes sediment accretion.

\section{CONCLUSIONS}

We compare the seismic stratigraphy of Sites $438 / 439$ of the deep-sea terrace and of Site 584 on the midslope terrace by using multichannel reflection profiles obtained from the Japan Trench continental slope off Sanriku, northeastern Japan. These profiles show that prominent downlap of the basal strata exists at places where the Cretaceous basement has been uplifted and also that surface reflectors toplap at the same places. We conclude that uplift of the basement is probably the cause of tensional stress in the overlying Neogene strata along the outer margins of the midslope terrace and deep-sea terrace. Development of the décollement above the graben appears to control subduction erosion or accretion.

\section{ACKNOWLEDGMENTS}

We thank JNOC for offering us data. We would like to express thanks to the Japanese IPOD committee. We also thank Roland von Huene, Dan Karig, and Bill Coulbourn for their valuable comments. We used HITAC M-280H/M-200H computer system at the Computer Centre of the University of Tokyo.

\section{REFERENCES}

Akiba, F., 1983. Revised Neogene diatom zonation in the middle-tohigh latitudes of the North Pacific. Kaiyo-Kagaku, 15:717-724. (In Japanese)

Hilde, T. W. C., 1983. Sediment subduction versus accretion around the Pacific. Tectonophysics, 99:381-397.

Kagami, H., Takahashi, H., Shishido, M., Kaneko, H., Fukuda, M., and Moriyama, M., 1980. Development of multichannel seismic profiling system. NEC Res. Dev., 59:12-19.

Kagami, H., Tokuyama, H., Fujioka, K., Igarashi, C., and Nasu, N., 1980. Preliminary report on multichannel seismic profiling across Japan Trench off Sanriku, NE Japan. Modern Sea Bottom Research. Proc. Symp. 1: Tokyo (Japan Hydrographic Association), pp. 49-59. (In Japanese)

Kagami, H., Tokuyama, H., Nasu, N., Yamazaki, T., Wachi, N., and Kaneda, Y., 1981. Unconformities of the continental margin off Sanriku coast. Kaiyo-Kagaku, 13:191-197. (In Japanese)

Kagami, H., Tokuyama, H., and Nishiyama, A., in press. Structure of the accretionary wedge at the Nankai Trough, off Shikoku, Japan.
In Kajiura, K. (Ed), Ocean Characteristics and Its Changes: Tokyo (Koseisha-Koseikaku).

Karig, D. E., Kagami, H., and Leg 87 Shipboard Scientific Party, 1983. Varied response to subduction in Nankai Trough and Japan Trench forearcs. Nature, 304(5922):148-151.

Moore, J. C., and Biju-Duval, B., 1984. Tectonic synthesis, Deep Sea Drilling Project Leg 78A: structural evolution of offscraped and underthrust sediment, northern Barbados Ridge complex. In BijuDuval, B., Moore, J. C., et al., Init. Repts. DSDP, 78A: Washington (U.S. Govt. Printing Office), 601-621.

Murauchi, S., and Ludwig, W. J., 1980. Crustal structure of the Japan Trench: the effect of subduction of ocean crust. In Scientific Party, Init. Repts. DSDP, 56, 57, Pt. 1: Washington (U.S. Govt. Printing Office), 463-469.

Nagumo, S., 1970. Development of the aftershore area and the block structure of the focal region of the 1968 Tokachi-Oki earthquake. Bull. Earthquake Res. Inst. Univ. Tokyo, 48:759-768.

Nagumo, S., Kasahara, J., and Koresawa, S., 1980. OBS airgun seismic refraction survey near Sites 441 and $434(\mathrm{~J}-1 \mathrm{~A}), 438$ and 439 (J-12), and proposed Site J-2B: Legs 56 and 57, Deep Sea Drilling Project. In Scientific Party, Init. Repts. DSDP, 56, 57, Pt. 1: Washington (U.S. Govt. Printing Office), 459-462.

Nasu, N., Tomoda, Y., Kobayashi, K., Kagami, H., Uyeda, S., Nagumo, S., Kushiro, I., Ojima, M., Nakazawa, K., Takayanagi, Y., Okada, H., Murauchi, S., Ishiwada, Y., and Ishii, Y., 1979. Multichannel Seismic Reflection Data Across the Japan Trench: Tokyo (Ocean Research Institute, University of Tokyo), IPOD-Japan Basic Data Series, No. 3.

Nasu, N., von Huene, R., Ishiwada, Y., Langseth, M., Burns, T., and Honza, E., 1980. Interpretation of multichannel seismic reflection data, Legs 56 and 57, Japan Trench transect. Deep Sea Drilling Project. In Scientific Party, Init. Repts. DSDP, 56, 57, Pt. 1; Washington (U.S. Govt. Printing Office), 489-503.

Saki, T., Honza, E., von Huene, R., Nasu, N., Ishiwada, Y., 1980. Analysis of downhole logs, Leg 57, Deep Sea Drilling Project. In Scientific Party Init. Repts. DSDP, 56, 57, Pt. 2: Washington (U.S. Govt. Printing Office), 1169-1186.

Takeuchi, H., and Saito, M., 1982. The system for multichannel seismic reflection analysis. Abstract Seismolog. Soc. Jpn., 1:208. (Abstract) (In Japanese)

Tokuyama, H., Kagami, H., Kong, Y. S., Igarashi, C., and Nasu, N., 1982. The recent results from the multichannel seismic profiling across the Japan Trench and the Nankai Trough. Modern Sea Bottom Research, Proc. Symp. 2: Tokyo (Japan Hydrographic Association), pp. 73-80. (In Japanese)

von Huene, R., Langseth, M., Nasu, N., and Okada, H., 1980. Summary, Japan Trench Transect. In Scientific Party Init. Repts. DSDP, $56,57, \mathrm{Pt}$. 1: Washington (U.S. Govt. Printing Office), 473-488.

Yoshii, T., 1977. Crustal and upper mantle structure in the northeastern Japan. Kagaku, 47:170-176. (In Japanese)

Date of Initial Receipt: 22 October 1984

Date of Acceptance: 10 June 1985 